\title{
Development of Electronic Learning Design 3 Vocational Education Program in Electronics Engineering Jakarta State University
}

\section{Arum Setyowati}

Electronics Engineering Vocational Education, State University of Jakarta, Jakarta, Indonesia

\section{Abstract}

This research is a type of Research and Development (R \& D) research which aims to develop learning design in Electronics 3 courses in Vocational Education in Electronic Engineering, Jakarta State University. The research method used in this study is to adopt the ADDIE instructional design model (Analyze, Design, Develop, Implement, and Evaluate). The learning design development phase includes: (1) Analysis phase; (2) Design stage; (3) Production stage; (4) Trial stage and (5) Evaluation stage. Data collection methods in this study include testing the feasibility of material content by

Corresponding Author:

Arum Setyowati

asetyowati@unj.ac.id

Received: 11 January 2019

Accepted: 14 February 2019

Published: 25 March 2019

Publishing services provided by Knowledge E

(c) Arum Setyowati. This article is distributed under the terms of the Creative Commons

Attribution License, which permits unrestricted use and redistribution provided that the original author and source are credited.

Selection and Peer-review under the responsibility of the 3rd ICTVET 2018 Conference Committee. 2 material experts, the feasibility of constructing media by 1 media expert as well as the feasibility test of use for 5th semester students of Vocational Education in Electronic Engineering Jakarta State University by giving questionnaires to these three aspects. Data analysis techniques using qualitative and quantitative descriptive analysis techniques. The results of this study indicate the percentage of the feasibility of developing learning design was $91.5 \%$ for content eligibility of material experts, $83.40 \%$ for the feasibility of media constructs from media experts, and $86.4 \%$ for the results of trial use of students. Of the three results, the development of learning design falls into the very feasible category to be used as an electronic learning design 3 in Electronic Engineering Vocational Education, Jakarta State University. The results of data analysis state that (1) Electronics 3 learning design can improve learning outcomes; (2) students have satisfaction when implementing this learning design. The findings of this study are to produce a comprehensive learning design in accordance with the objectives of Electronics learning 3.

Keywords: instructional design, ADDIE, electronics 3.

\section{Introduction}

The learning process in the form of innovation can be done, in reality it is very necessary to innovate in learning in the classroom by being oriented to an instructional system (learning). Effective instructional design focuses on performing authentic tasks, complex knowledge, and genuine problems. Thus effective instructional design promotes 
high fidelity between learning environments and actual work settings [1]. Innovation in learning is very necessary so that the learning goals that have been set in specific instructional can be achieved $[2,3]$. In daily practice, the instructors are seen trapped in routine instructional activities so they forget to innovate. Even though instructional innovation is needed so that teachers can get out of the routine that has happened so far. Generally the focus of instructional practice is how the teaching material can be delivered thoroughly, not how learning objectives that have been designed can be achieved.

Morrison, Ross \& Kemp stated that the Snellbecker and others have a design proposal that is the linking science describe by Dewey. We agree with Snellbecker and see instructional design as the process for designing instruction based on sound practices [4]. The design of learning according to Raiser \& Demsey is as follows: Instructional Design (ID) a systematic process that is employed to develop education and training programs in a consistent and reliable fashion. Instruction design is a complex process that is creative, active and interactive [5]. Thus, a learning design model is needed that can be applied easily by the instructor.

\section{Methods}

The research method used in this study is to adopt the ADDIE instructional design model. ADDIE's instructional design model can be used for product development. Robert Maribe Branch stated: ADDIE is an acronym for Analyze, Design, Develop, Implement, and Evaluate.

ADDIE is a product development concept. The ADDIE concept is applied here to constructing performance-based learning. The educational philosophy for this application of ADDIE is that student learning is centered, innovative, authentic, and inspirational [6]. ADDIE was developed with 5 (five) steps or development phases including: Analysis, Design, Development, Implement and Evaluate.

The ADDIE model has several advantages and disadvantages. The strength of this model is that the implementation of the ADDIE learning system design model is done systematically and systemically. The disadvantage of this model lies in the analysis stage because the developer is expected to be able to analyze two components of the students first by dividing the analysis into two, namely performance analysis and needs analysis. Both of these components are very necessary in instructional design. 


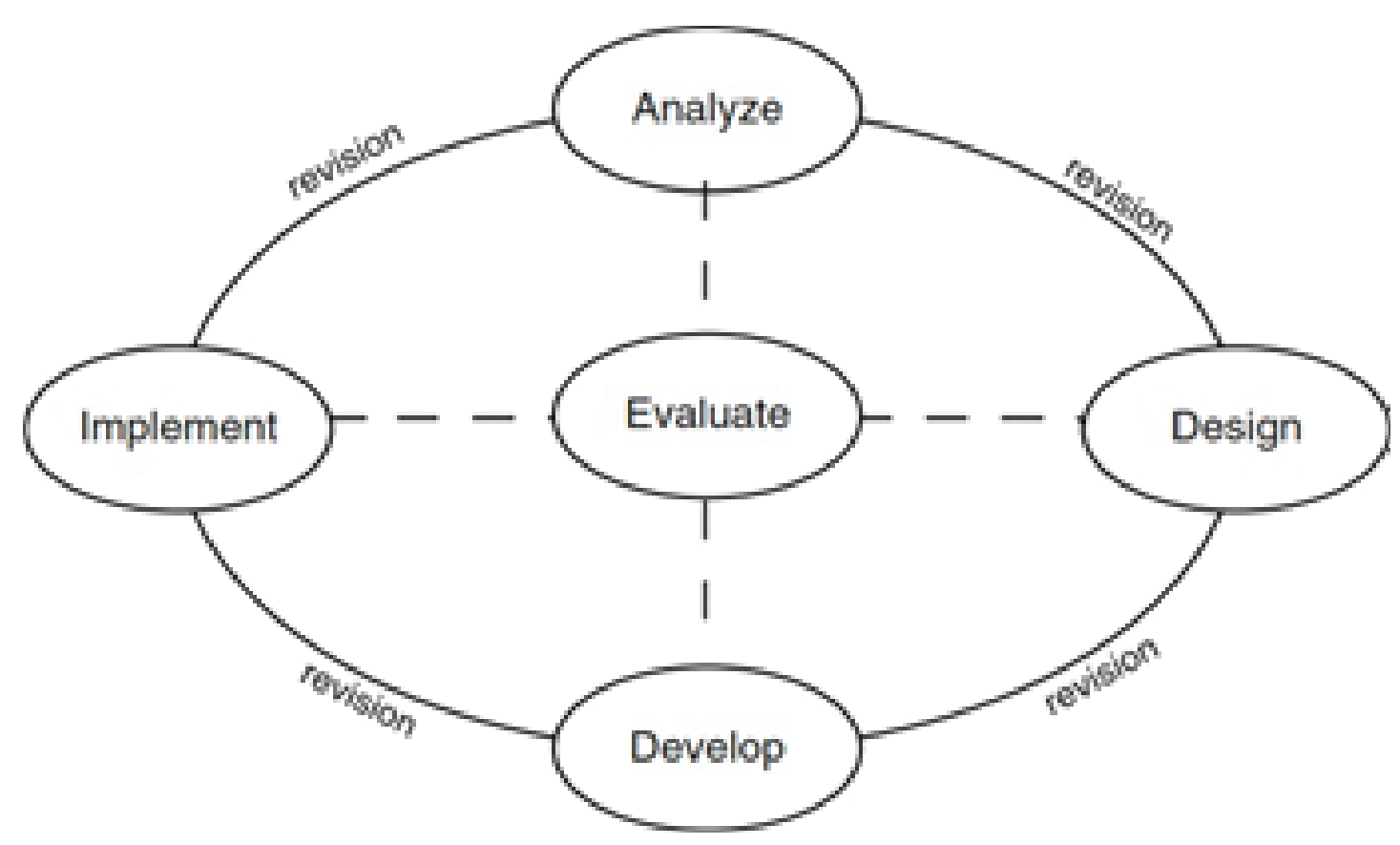

Figure 1: The ADDIE Concept.

The target of the development of electronic learning design research 3 , the subject of Operational Amplifiers was 63 students in the 5th semester of Vocational Education in Electronic Engineering, Jakarta State University. Lattice validation questionnaire material experts have several indicators, namely the suitability of the material with the lecture program, material grammar, suitability of images and illustrations with the material, making it easier for students to understand the material, increasing student motivation to learn and the quality of practice questions.

Grid validation questionnaire media experts have several indicators, namely the use of language, image quality, layout design, text format, making it easier for students to understand the material and increase students' motivation to learn. The questionnaire for students has several indicators, namely image quality, layout design, text format, making it easier for students to understand the material and increase students' motivation to learn.

In the evaluation phase, the development of the Electronics 3 learning design on the subject of Operational Amplifiers will be evaluated and assessed by several expert teams. This phase aims to examine the validation and feasibility of material content, the feasibility of constructing technical designs and the benefits of developing this learning media. Evaluation from material experts on the development of Electronics learning design 3, the subject of Operational Amplifier was carried out by 2 lecturers who taught Basic Electronics 3 courses at the State University of Jakarta. The aim is to find out the material quality and the benefits of developing this learning design. 
Evaluation from media experts on the development of learning design on the subject of Operational Amplifier was conducted by instructional media lecturers at Jakarta State University. The aim is to find out the quality of engineering design, communication with users and the benefits of developing this learning design.

The trial phase was carried out to students to see the extent to which the development of Electronic learning design 3, the subject of Operational Amplifiers attracted students in learning. This learning design development trial was conducted to obtain data on application feasibility on the development of learning design that was assessed from the aspects of appearance, technical, material and benefits for 6th semester students of Jakarta State University.

Data collection techniques in this study used a questionnaire. The questionnaire used included three types according to their functions, namely questionnaires for material experts, questionnaires for media experts and questionnaires for students. The questionnaire uses a Likert scale with a measuring scale of 5 .

\section{Results and Discussion}

The testing phase is for material experts to test content and media experts in terms of constructs. Figure 2 shows the percentage of the results of the assessment of the feasibility of the media content by material experts.

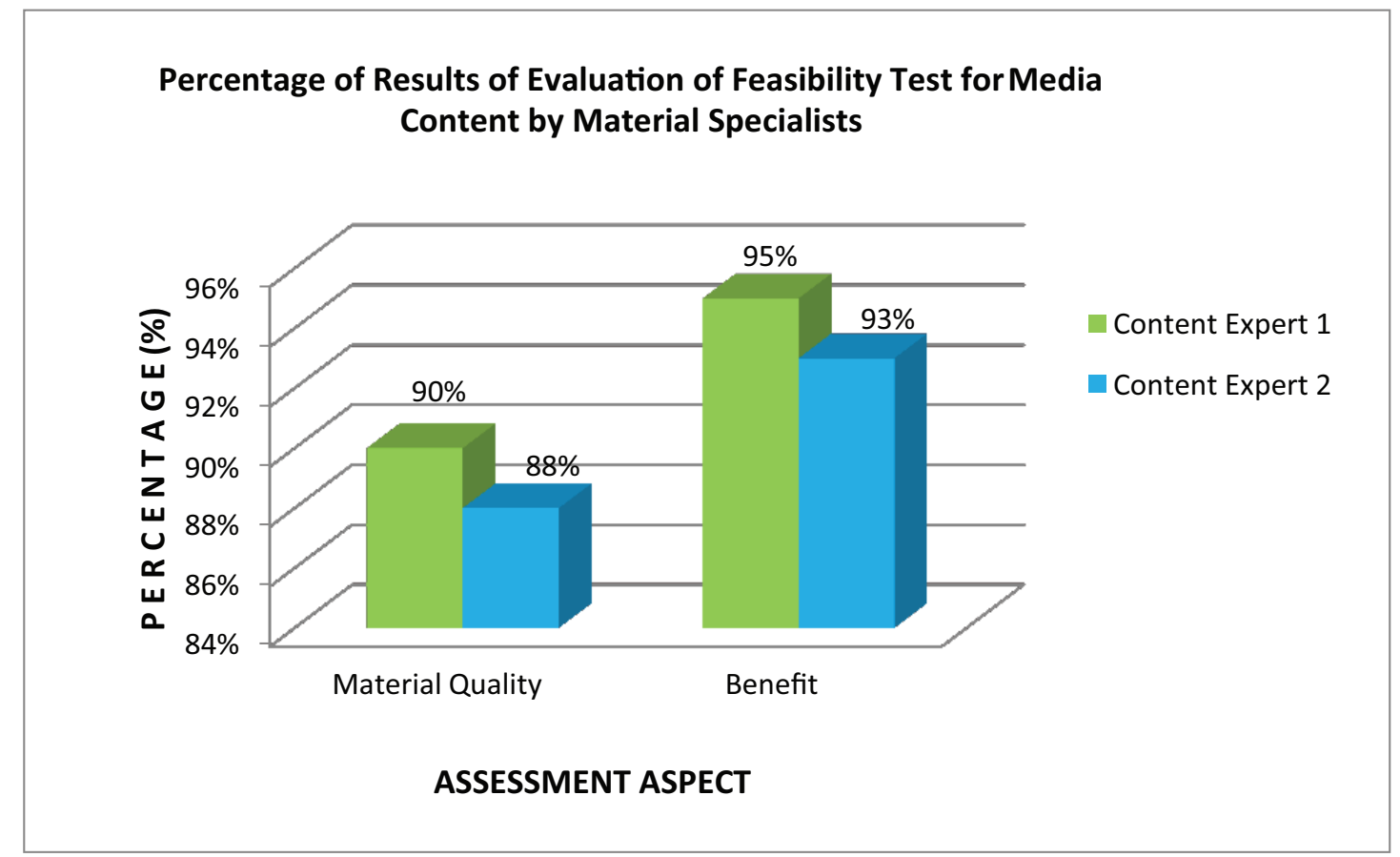

Figure 2: Bar Diagram Percentage of Results of Evaluation of Feasibility Test for Media Contents by Material Experts. 
In Figure 2, the percentage of the results of the feasibility test obtained from material experts is viewed from the aspect of material quality by $90 \%$ and $88 \%$ with an average of both percentages of $89 \%$. However, on the aspect of benefits obtained from two material experts, namely obtaining $95 \%$ and $93 \%$ with an average of both percentages of $94 \%$. The percentage of the results of the overall feasibility test results obtained from two material experts in terms of material quality aspects and benefits of $91.5 \%$, the development of learning design is categorized as very feasible to be used in Electronics 3 courses in Vocational Education in Electronics Engineering Jakarta State University. Figure 3 shows the percentage of results of the assessment of media construct feasibility by media experts.

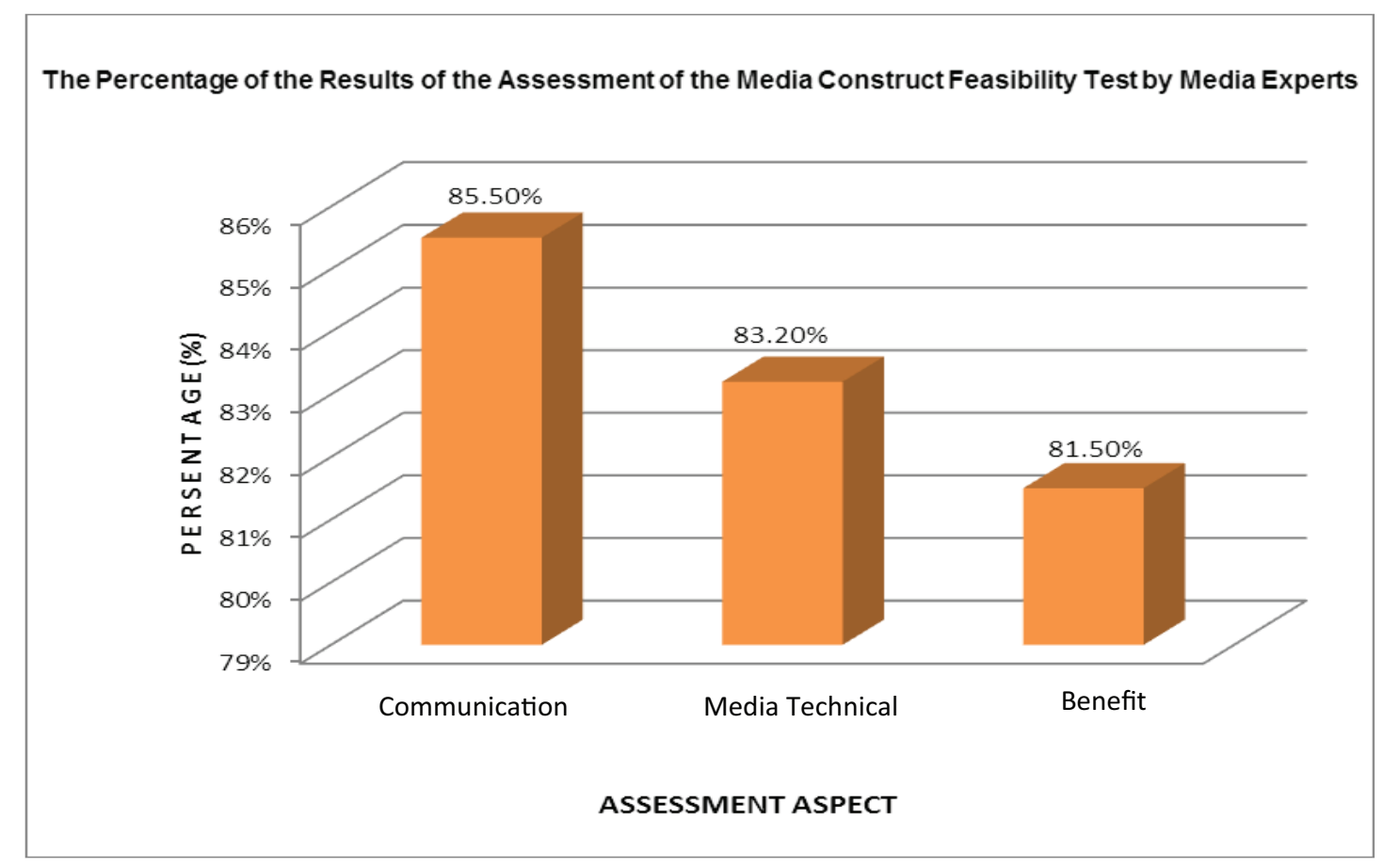

Figure 3: Bar Diagram of the Percentage of Evaluation Results of the Media Content Feasibility.

In Figure 3, the percentage of the results of the assessment of the media construct feasibility test by media experts in terms of communication with users is $85.5 \%$, the technical design aspects of the media are $83.2 \%$ and the benefit aspects are $81.5 \%$. The results of the overall construct feasibility assessment (communication aspects with users, media technical design, and benefit aspects) were $83.4 \%$, so the development of learning media was categorized as very feasible for use in Electronics 3 courses in Vocational Education in Electronic Engineering State University Jakarta. Figure 4 shows the percentage of the results of the assessment of the feasibility test of media usage by students in terms of appearance, technical, material and benefit aspects. 


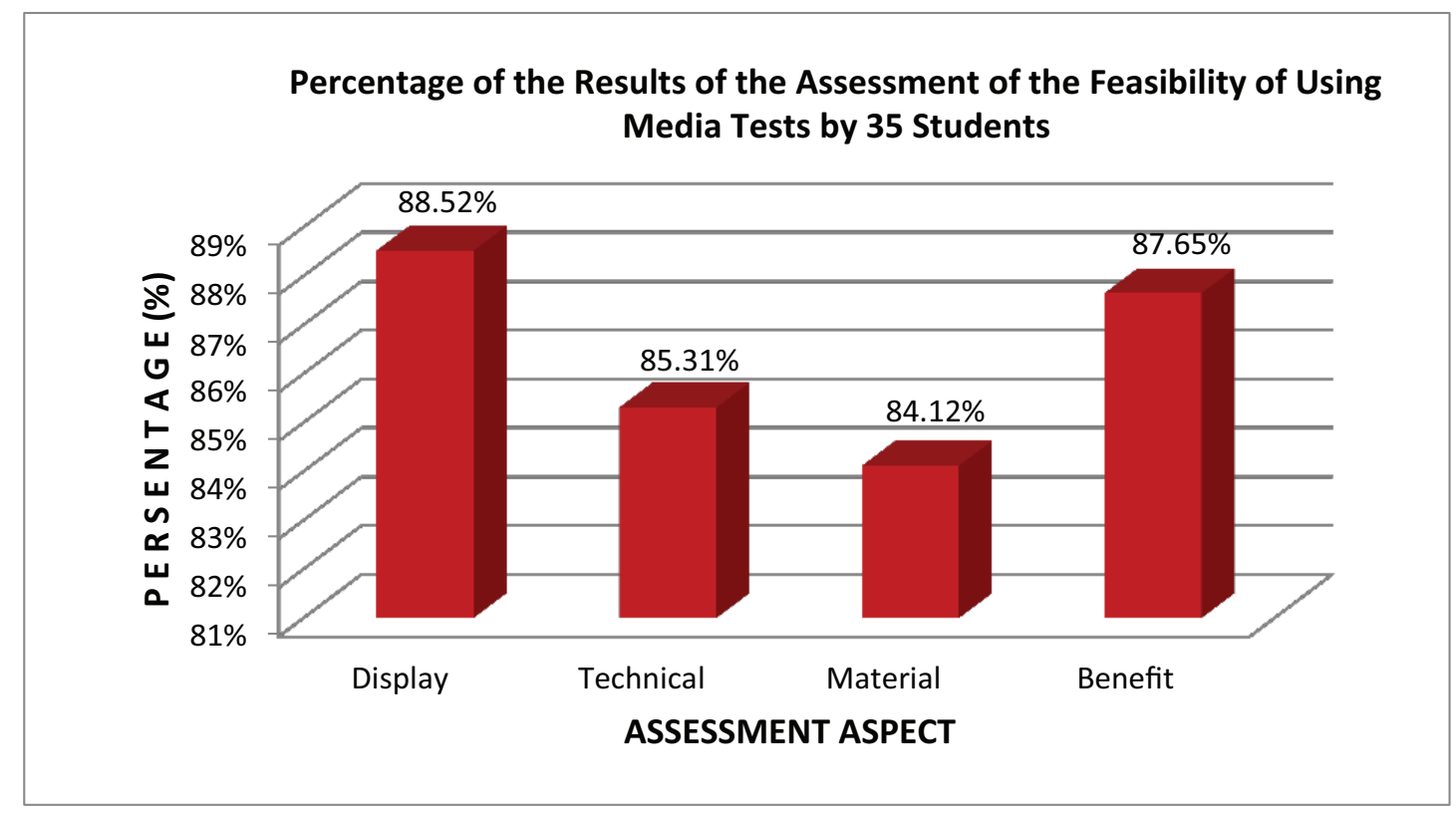

Figure 4: Stem Diagram Percentage of Results of Assessment of Media Usage Tests by Students.

In Figure 4, the percentage of the results of the assessment of the use of learning media by students in terms of appearance aspects $88.52 \%$, technical $85.31 \%$, material $84.12 \%$ and benefits $87.65 \%$. The results of the assessment of media use tests were obtained from the average of 35 students at $86.4 \%$. So it can be concluded that this learning media is very feasible to be used in Electronics 3 courses in Vocational Education in Electronic Engineering, Jakarta State University.

\section{Conclusion}

Based on the findings and discussion of the results of the study, it can be concluded, (1) learning activities begin with the learning design process; (2) Effective teaching materials, namely communicative teaching materials, so that they can guide students to independent learning; (3) the level of feasibility of developing learning media seen from three aspects, namely the feasibility aspects of content, constructs, and usage tests.

From the research data, the percentage of the value of the feasibility test of the media content by material experts is $91.5 \%$, the results of the media construct feasibility test percentage by media experts is $83.4 \%$ and the percentage of test media usage by students is $86.4 \%$. The level of feasibility of the media based on the testing of media use carried out in 5th semester students Vocational Education Electronics Engineering Jakarta State University is very feasible to use. 


\section{References}

[1] Branch, R.M. (2009). Instructional Design: The ADDIE Approach. New York, NY: Springer. p. 1.

[2] Mustafa Serdar Koksal. (2009). An instructional design model to teach nature of science Asia-Pacific on Science Learning and Teaching. Vol.10, p.1.

[3] Dewi Purnama Sari, Edy Surya. (2017). Development the module of mathematics statistics 1 by using the model of dick and carey design. International journal of sciences: basic and applied research (IJSBAR), Vol. 34, No 1.

[4] Morrison, Ross \& Kemp. (2007). Effective Designing Instructions, 5th Edition. Baskerville: John Wiley \& Sons, Inc.

[5] Robert A. Raiser \& John V Demsey. (2007). Trends and Issues In Instructional Design and Technology, Second Edition. Columbus: Person Education, Inc.

[6] Branch, R.M. (2009). Instructional Design: The ADDIE Approach. New York, NY: Springer. p. 2. 